\title{
ANALYTICAL FORMULATION OF THE CORRECTION FACTOR APPLIED IN EINSTEIN AND BARBAROSSA EQUATION (1952)
}

\author{
ACHANTA RAMAKRISHNA RAO, BIMLESH KUMAR
}

Department of Civil Engineering, IISc, Bangalore-India; mailto: ark@civil.iisc.ernet.in; bimlesh.iisc@gmail.com

Einstein-Barbarossa velocity or resistance equation (1952) is widely used to find resistance to flow in alluvial channel. In order to validate the equation in all ranges (smooth to rough); they introduced a correction factor based on the Nikuradse measurement. This correction factor is determined from the graphical method, which can be erroneous. Present work reanalyzes the Nikuradse measurements and gives an analytical formulation for the correction factor.

KEY WORDS: Alluvial Channel, Einstein-Barbarossa Equation, Logarithmic Velocity Profile, Hydraulic Rough Boundary, Hydraulic Smooth Boundary, Sediment Transport.

Achanta Ramakrishna Rao, Bimlesh Kumar: ANALYTICKÁ FORMULÁCIA KOREKČNÉHO FAKTORA APLIKOVANÉHO V EINSTEINOVEJ-BARBAROSSOVEJ ROVNICI (1952). J. Hydrol. Hydromech., 57, 2008, 1; 8 lit., 2 obr.

Einsteinova-Barbarossova rovnica (1952) sa často používa na určenie odporu voči prúdeniu v kanáloch. Autori do nej zaviedli korekčný faktor, založený na meraniach Nikuradzeho, aby overili platnost' rovnice v celom rozsahu drsností (od hladkých stien po drsné). Tento korekčný faktor sa určuje grafickou metódou, ktorá môže viest’ k chybným výsledkom. V tejto práci sa znova analyzujú výsledky Nikuradzeho meraní a je navrhnutá analytická formulácia na výpočet korekčného faktora.

KLÚČOVÉ SLOVÁ: aluviálny kanál, Einsteinova-Barbarossova rovnica, logaritmický profil rýchlosti, hydraulicky drsné hranice, hydraulicky hladké hranice, transport sedimentov.

\section{Introduction}

One of the most important aspects in open channel flow computations is the estimation of hydraulic flow resistance. Knowledge about the hydraulic resistance is important for the understanding and handling of engineering and environmental problems involving rivers and streams. Its estimation has direct or indirect consequences in the planning, design, and operation of water resources projects including flood control, erosion control and channel stabilization.

In an alluvial stream, the mobile bed formed by cohesionless alluvium is seldom flat; rather, it is covered by periodic bed deformations, known as bed forms. These bed forms change in type and size depending on the flow conditions. They constitute an important obstacle to the flow, and thus, the resistance of alluvial channels changes as bed forms change.
Einstein and Barbarossa (EB) in 1952 provided a semi-analytical method for the computation of flow resistance in alluvial channels. Although the technique is very old, it is still probably the most widely quoted of any existing techniques. They suggested that the resistance of an alluvial stream consists of bed resistance and bank resistance. Furthermore, the bed resistance consists of grain friction and bed form resistance. According to EB (1952), the shear stress or drag force acting along an alluvial bed can be divided into two parts, i.e,

$$
\tau=\tau^{\prime}+\tau^{\prime \prime}=\gamma S\left(R_{b}^{\prime}+R_{b}^{\prime \prime}\right),
$$

where $\tau$ - the total drag force acting along an alluvial bed, $\tau^{\prime}$ and $\tau^{\prime \prime}$ - the drag force due to grain roughness and form roughness, respectively, $\gamma-$ the specific weight of water, $S$ - the energy or channel slope, and $R_{b}^{\prime}$ and $R_{b}^{\prime \prime}$ - the hydraulic radii due to grain roughness and form roughness, respectively. The grain friction denotes the resistance to a two- 
dimensional flow, which is not affected by side banks, with a plane bed. The grain friction can be described by the following equation (EB 1952):

$$
\frac{\bar{u}}{u^{*}}=5.75 \log \left(12.2 \frac{R_{b}^{\prime} \chi}{k_{s}}\right),
$$

where $\bar{u}-$ the average velocity, $u^{*}-$ shear velocity due to grain roughness $=\left(\mathrm{g} R_{b}^{\prime} S\right)^{0.5}, k_{s}-$ a representative roughness, which is taken as $D_{65}$, the particle size of bed material of which 65 per cent by weight is finer and $\chi-\mathrm{a}$ function of $k_{s} / \delta$, where $\delta$ is the thickness of laminar sublayer $\left(=11.6 \mathrm{v} / u^{*}\right)$. The relationship between $\chi$ and $k_{s} / \delta\left(=\mathrm{R}^{*} / 11.6\right.$, $\mathrm{R}^{*}=u^{*} k_{s} / \gamma$ and is called particle Reynolds number) has been presented through a graph based on the measurement of Nikuradse's experimental data on sand roughened pipes.

Although the EB (1952) equation was intended to be universal, embracing all sediment sizes and depth of flow, in practice it has on occasions given results which have been clearly very considerably in error (Smith, 1970). It may be or may not be, but the authors feel that can be attributed to the graphical determination of the parameter $\chi$. Although Smith (1970) has presented the modified bed-form resistance diagram, he kept the same correction factor as devised by the EB (1952). Brownlie (1981) has analyzed the Nikuradse measurements and presented the three different and distinct equations in order to measure the $\chi$ analytically or explicitly.

As said earlier, the graphical relationship between $\chi$ and $k_{s} / \delta$ has been derived based on the Nikuradse measurement, by carefully analyzing the Nikuradse measurement one distinct and unique semi-empirical relationship can be obtained, which can hopefully replace the graphical determination of $\chi$.

\section{Analytical approach}

The wide acceptance of the log law of velocity distribution could be due to the fact that it can be justified with certain theoretical arguments, for example, Prandtl's mixing length assumption, von Karman's dimensional reasoning or Millikan's asymptotic analysis (Kundu et al., 2004). However, these arguments can be considered theoretically correct only in a limited region of flow, although the log law may apply practically beyond the region. Generally, it is believed that wall-bounded turbulent flows are characterized by two kinds of length scales. In the inner region near a smooth boundary, fluid viscosity is important, and thus the acceptable length scale is the viscous length scale. In the outer region that is sufficiently far from the boundary, flow inertia is significant. In addition, it is assumed that the shear velocity is a global velocity scale applicable both for the inner and outer region (Nezu and Nakagawa, 1993).

The established laws of velocity distribution for turbulent flows can be expressed as:

$$
\begin{aligned}
& \frac{u}{u^{*}}=A \ln \frac{y u^{*} / v}{a^{\prime}} \text { for smooth pipes and } \\
& \frac{u}{u^{*}}=A \ln \frac{y / k_{s}}{b^{\prime}} \text { for rough pipes, }
\end{aligned}
$$

where $A$ - the inverse of Von-Karman's constant (= 2.45), a' and b' are constants, $u$ - the velocity at a distance $y$ measured from the pipe wall, $u^{*}-$ the friction velocity, $k_{s}$ - the Nikuradse's sand roughness height and $v$ is the kinematic viscosity of the fluid.

As seen from the Eqs. (3) and (4), the characteristic length $l$ for non-dimensionalizing the depth $y$ is $v / u_{*}$ for smooth turbulent flows and $k_{s}$ for rough turbulent flows. So it is proposed that $l$ is actually a linear combination of both $\left(v / u^{*}\right.$ and $\left.k_{s}\right)$ with a correction function, $\phi$ covering the all ranges i.e., smooth, transition and rough regimes of turbulent flows. Thus

$$
l=\left(a^{\prime} \frac{v}{u^{*}}+b^{\prime} k_{s}\right) \phi\left(\mathrm{R}^{*}\right),
$$

where $\mathrm{R}^{*}$ - equal to $k_{s} u^{*} / v$ and the correction function $\phi$ is assumed to be a function of $R_{*}$. At $R^{*} \rightarrow 0$, pipe is said to be in smooth condition and for rough pipe $\mathrm{R}^{*} \rightarrow \infty$.

For large values of $v / u^{*}$ the term $a^{\prime} v / u^{*}$ dominates making the second term $b^{\prime} k_{s}$ negligible in comparison with it. So also for small values of $v / u^{*}$, the second term becomes important allowing the neglect of the first term. Thus the velocity laws covering all the three regimes can be summarized as, 


$$
\begin{aligned}
& \frac{u}{u^{*}}=A \ln \frac{y}{\left(a^{\prime} \frac{v}{u^{*}}+b^{\prime} k_{S}\right) \phi\left(\mathrm{R}^{*}\right)} \Rightarrow \\
& \Rightarrow A \ln \frac{y / k_{S}}{\left(\frac{a^{\prime}}{R^{*}}+b^{\prime}\right) \phi\left(\mathrm{R}^{*}\right)} .
\end{aligned}
$$

Now, if a condition that $\phi\left(\mathrm{R}^{*}\right)=1$ for both when $R^{*} \rightarrow 0$ and $\infty$ is imposed due to established physical conditions of hydraulically smooth and rough regions, Eq. (6) reduces to Eqs. (3) and (4) respectively.

By assuming Eq. (6) valid for the entire pipe radius $(r)$, an expression for $\bar{u} / u^{*}$ can be obtained by integrating Eq. (6).

$$
\frac{\bar{u}}{u^{*}}=A \ln \left(\frac{r / k_{S}}{B^{*}}\right)
$$

where

$$
B^{*}=\left[\frac{a+b \mathrm{R}^{*}}{\mathrm{R}^{*}}\right] \phi\left(\mathrm{R}^{*}\right) \text {. }
$$

Resistance equation for free surface flows can be obtained by Eq. (7) by suitably adjusting the terms in it depending upon the geometry of flow region between pipes and free surface flows. If logarithmic law of velocity distribution is assumed to be valid throughout the radius, $r$, in case of pipes and the flow depth, $D$, in case of free surface flows; then $r$ is to be replaced by $D$ and a multiplying factor $\mathrm{e}^{-0.5}$ is to be introduced to $B^{*}$ in Eq. (7) as shown in Fig. 1.

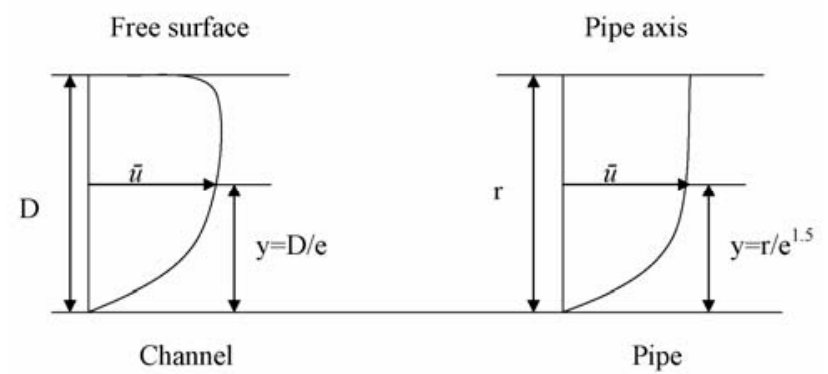

Fig. 1. Velocity profile in channel and pipe. Obr. 1. Profily rýchlostí v kanáli a v potrubí.

Integrating the velocity profile over flow depth, it follows that $\bar{u}$ is equal to the value of $u$ corresponding to dimensional level $\frac{y}{D}=1 / e$ for free surface flows and $\frac{y}{r}=1 / e^{1.5}$ for pipe flows (Raudkivi,1967).

Point of application of average velocity in free surface flows:

$\bar{u}=\frac{1}{D} \int_{0}^{D} u(y) d y=\frac{u^{*}}{D} \int_{0}^{D} A \ln \frac{y}{C} d y$ (where $\mathrm{C}$ is someconstant)

$\Rightarrow \frac{\bar{u}}{u^{*}}=A[\ln (D)-1]=\frac{\bar{u}}{u^{*}}=A[\ln (D)+\ln (0.37)]$

$\frac{\bar{u}}{u^{*}}=A[\ln 0.37 D] \Rightarrow$ point of application of $\bar{u}$ is $y=0.37 D$

$\frac{y}{D}=0.37 \approx 1 / e$

Same principlecan be applied in the turbulent pipe flow. However Pao (1961) has given an emprical formula to calculate $y / r$, which is equal to $0.216 \approx 1 / e^{1.5}$

For Pipe $\frac{\bar{u}}{u^{*}}=A \ln \frac{y / k_{S}}{B^{*}} e^{1.5}$ and $\frac{\bar{u}}{u^{*}}=A \ln \frac{y / k_{S}}{B} e$ (in case of channels).

Now comparing, $\frac{e}{B}=\frac{e^{1.5}}{B^{*}}$

$B=e^{-0.5} B^{*}$ 
For free surface flows, it can be written as:

$\frac{\bar{u}}{u^{*}}=A \ln \frac{D / k_{S}}{e^{-0.5} B^{*}}$.

Or the resistance equation for free surface flows can be written as:

$\frac{\bar{u}}{u^{*}}=A \ln \frac{D / k_{S}}{B}$.

It is of interest to express Eq. (11) in a form given by EB (1952) as:

$\frac{\bar{u}}{u^{*}}=A \ln \frac{12.2 D \chi}{k_{s}}$

where $\chi$ - a correction factor roughness introduced by $\mathrm{EB}(1952)$ and it is a function of $k_{s} / \delta$ or $\mathrm{R}^{*} / 11.6$. Thus the expression for $\chi$ can be expressed as:

$\chi=\frac{1}{12.2 B}=\frac{1}{7.4} \frac{\mathrm{R}^{*}}{\left(a+b \mathrm{R}^{*}\right) \phi\left(\mathrm{R}^{*}\right)}$.

Now re-analyzing Nikuradse experimental data (1937) on pressure drop measurements in sand roughened pipes, the following values of $a=0.444$ and $b=0.135$ are obtained and an expression for $\phi\left(\mathrm{R}^{*}\right)$ is given by

$\phi\left(\mathrm{R}^{*}\right)=1-0.55 e^{-0.33\left[\ln \left(\frac{\mathrm{R}^{*}}{6.5}\right)\right]^{2} .}$
Substituting the values of $a, b$ and $\phi\left(\mathrm{R}^{*}\right)$ in Eq. (13), $\chi$ can now be analytically determined from the following equation:

$\chi=\frac{1}{7.4} \frac{\mathrm{R}^{*}}{\left(0.444+0.135 \mathrm{R}^{*}\right)\left(1-0.55 e^{\left.-0.33\left[\ln \left(\frac{\mathrm{R}^{*}}{6.5}\right)\right]^{2}\right)}\right.}$

In order to compute $\chi$, EB (1952) have given a curve relating $\chi$ and $11.6 \mathrm{R}^{*}$. However, one can now use Eq. (15) for the determination of $\chi$ instead of their curve. The validity of the expression for $\chi$ in Eq. (15) is shown in Fig. 2 by using the Nikuradse's experimental data.

\section{Conclusions}

1. In sediment transport, the curve given by EB (1952) can now be replaced by the analytical expression of Eq. (14).

2. Eqs. (7) and (11) are valid for all the three roughness regions, can now be used as a unique equation to find the resistance characteristics of smooth as well as sand roughened pipes and open channels respectively.

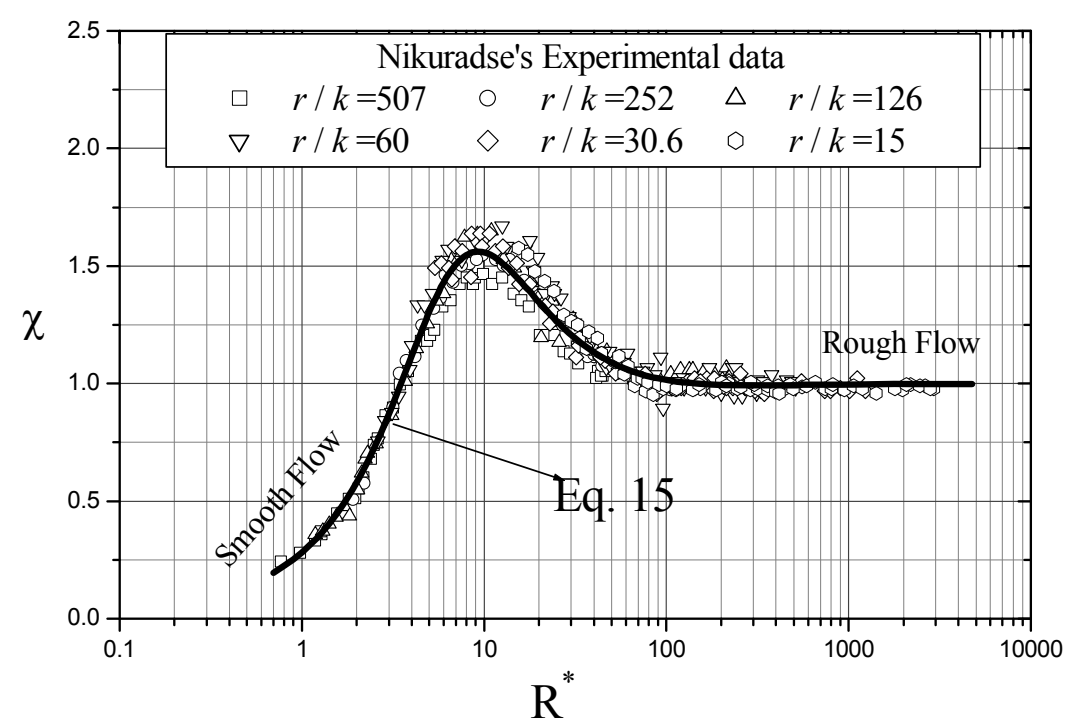

Fig. 2. Validity of $\chi$.

Obr. 2. Platnost' $\chi$. 
List of symbols

A - inverse of Von-Karman's constant,

a' - constant,

$a$ - constant,

b' - constant,

$b$ - constant,

$B_{*}$ - function of $\mathrm{R} *$

$D$ - flow depth in open channel [m],

$D_{65}$ - the particle size of bed material of which 65 per cent by weight is finer [m],

$k_{s}-$ representative roughness scale $=D_{65}[\mathrm{~m}]$,

$r$ - pipe radius [m],

$\mathrm{R}$ - Reynolds number,

$\mathrm{R}^{*}$ - particle Reynolds number,

$R_{\mathrm{b}}^{\prime}$ - the hydraulic radius due to grain roughness [m],

$R^{\prime \prime}{ }_{b}$ - the hydraulic radius due to form roughness [m],

$S$ - the energy or channel slope,

$\bar{u}-$ the average velocity $\left[\mathrm{m} \mathrm{s}^{-1}\right]$,

$u^{*}$ - shear velocity due to grain roughness $=\left(\mathrm{g}^{\prime}{ }_{b} S\right)^{0.5}$ $\left[\mathrm{m} \mathrm{s}^{-1}\right]$,

$\chi-$ correction factor $=\mathrm{a}$ function of $k_{S} / \delta$,

$\delta-11.6 v / u^{*}$, the thickness of laminar sub layer,

$v-$ kinematic viscosity $\left[\mathrm{m}^{2} \mathrm{~s}^{-1}\right]$,

$\tau-$ the total drag force acting along an alluvial bed [N],

$\tau^{\prime}$ - the drag force due to grain roughness [N],

$\tau^{\prime \prime}$ - the drag force due to form roughness [N],

$\gamma \quad$ specific weight of water $\left[\mathrm{N} \mathrm{m}^{-3}\right]$.

\section{REFERENCES}

BROWNLIE W.R., 1981: Re-examination of Nikuradse Roughness Data. J. Hydraulics Div., ASCE, 107, 1, 115-119 .

EINSTEIN H.A. and BARBAROSSA N.L., 1952: River Channel Roughness. Transactions of the ASCE, 117, 1121-1132.

KUNDU P.K., COHEN, I.M. and HU H.H., 2004: Fluid mechanics. $3^{\text {rd }}$ ed., Amsterdam, Boston, Elsevier Academic Press.

NEZU I. and NAKAGAWA H., 1993: Turbulence in openchannel flows. Rotterdam, Netherlands, A.A. Balkema.

NIKURADSE J., 1937: Laws of flow in rough pipes. NACA Tech. Mem, 1292.

PAO R.H.F., 1961: Fluid Mechanics. Wiley, New York.

RAUDKIVI A.J., 1967: Loose Boundary Hydraulics. Pergamon Press.

SMITH K.V.H., 1970: The Einstein-Barbarossa diagram for computing bed-form resistance in alluvial channels. Proc. Instn. Civ. Engrs., 46, 6, 169-184.
Received 23. August 2007

Short communication accepted 16. October 2008

\section{ANALYTICKÁ FORMULÁCIA KOREKČNÉHO FAKTORA APLIKOVANÉHO V EINSTEINOVEJ- -BARBAROSSOVEJ ROVNICI (1952)}

\section{Achanta Ramakrishna Rao, Bimlesh Kumar}

1. Krivky, charakterizujúce transport sedimentov v rovnici EB (1952) môžu byt' nahradené analytickým výrazom, vyjadreným rov. (14).

2. Rov. (7) a (11) sú platné pre všetky tri oblasti drsností a môžu byt' použité na získanie charakteristík odporu voči prúdeniu pre všetky tri oblasti drsností, t.j. pre hladké, ako aj pieskom zdrsnené potrubia, aj pre otvorené kanále.

\section{Zoznam symbolov}

A - invezná Von-Karmanova konštanta,

a' - konštanta,

a - konštanta,

b' - konštanta,

$b$ - konštanta,

$B_{*}$ - funkcia $R *$

$D$ - híbka prúdu v otvorenom kanáli [m],

$D_{65}$ - vel'kost' častíc v materiáli koryta, od ktorých $65 \%$ častíc, vyjadrených v hmotnostných percentách, je menších [m],

$k_{s}$ - reprezentatívna charakteristika mierky drsností $=D_{65}$ [m],

$r$ - polomer potrubia [m],

$\mathrm{R}$ - Reynoldsovo číslo,

$\mathrm{R}^{*}$ - Reynoldsovo číslo pre častice,

$R_{\mathrm{b}}^{\prime}$ - hydraulický polomer, spôsobený drsnost'ou častíc [m],

$R_{b}{ }_{b}$ - hydraulický polomer, spôsobený drsnost'ou tvaru [m],

$S$ - energia alebo sklon kanála,

$\bar{u}$ - priemerná rýchlost' $\left[\mathrm{m} \mathrm{s}^{-1}\right]$,

$u^{*}$ - trecia rýchlost', spôsobená drsnost'ou častíc $\left(\mathrm{g} R_{b}^{\prime} S\right)^{0.5}$ $\left[\mathrm{m} \mathrm{s}^{-1}\right]$,

$\chi \quad$ - korekčný faktor, funkcia $k_{s} / \delta$,

$\delta-11.6 v / u^{*}$, hrúbka laminárnej subvrstvy,

$v$ - kinematická viskozita $\left[\mathrm{m}^{2} \mathrm{~s}^{-1}\right]$,

$\tau-$ celková sila trenia pôsobiaca pozdíž kanála [N],

$\tau^{\prime} \quad$ - sila trenia spôsobená drsnost'ou častíc [N],

$\tau^{\prime \prime}$ - sila trenia spôsobená, drsnost'ou tvarovou [N],

$\gamma-$ merná hmotnost' vody $\left[\mathrm{N} \mathrm{m}^{-3}\right]$. 